\title{
Reconstruction of the Chalet of the Countess of Edla: preliminary evaluation of the effects of fire in the architectural surfaces
}

Reconstrução do Chalet da Condessa de Edla: avaliação preliminar dos efeitos do fogo nas superfícies arquitectónicas

Graça Horta

Bachelor in Conservation, Conservator-Restorer, Instituto dos Museus e da Conservação, Lisbon, Portugal, hortae@gmail.com

José Maria Lobo de Carvalho

MA Cons.(York)/Architect, Parques de Sintra - Monte da Lua, S.A., Sintra, Portugal,

jose.lobodecarvalho@parquesdesintra.pt

V. M. Rato

Ph.D./Assistant Professor, Fac. Ciências e Tecnologia - Univ. Nova de Lisboa, Lisbon, Portugal,

vnmr@fct.unl.pt

\begin{abstract}
This paper addresses the effects of fire on historic surfaces through the scientific analysis of the original mortars and pigments of the Chalet of the Countess of Edla, located in the Park of Pena (Sintra, Portugal). It is intended as a first approach to the study and characterization of the historical fabric in the context of the ongoing restoration project, promoted by Parques de Sintra-Monte da Lua, SA.
\end{abstract}

\section{Keywords}

Pena; Countess of Edla; fire; mortars; decorative render.

\section{Resumo}

O presente trabalho aborda os efeitos do fogo em superfícies históricas através da análise científica das argamassas e dos pigmentos originais do Chalet da Condessa de Edla, localizado no Parque da Pena em Sintra. Tem como objectivo constituir-se como uma primeira abordagem ao estudo e caracterização deste património histórico no contexto do projecto de restauro em curso, promovido pela empresa Parques de Sintra-Monte da Lua, SA.

Palavras-chave

Pena; Condessa de Edla; fogo; argamassas; reboco decorativo. 


\section{Introduction}

The Chalet is a romantic cottage built between 1864-69 by the King-consort Dom Fernando II and his second wife, the Countess of Edla, within the Park of Pena, surrounding the Royal Palace (figure 1), part of the wider area listed by UNESCO as Cultural Landscape of Sintra, in 1995. This building is a remarkable example of romantic architecture with significant influences of the Northern European and American mountain cottages, following the Countess's original countries of birth and adoption (Germany and USA). Being a small scale structure, it was built as a personal retreat, away from the court life, with a particular decorative scheme that includes painted exterior renders simulating wood planks and the extensive use of cork covering doors and window frames, the balconies and the roof decoration elements. In the interior, the building exhibits an interesting decorative scheme of different painted architectural surfaces with coloured patterns and geometric designs.

After the end of the Monarchy in 1910, the building was occasionally used and remained neglected for decades, until a fire of unknown causes destroyed it severely in July 1999. It is believed that the fire started over night and was detected in the following morning, resulting in a slow combustion of the wooden elements of the roof and upper pavements, including the majority of the internal partition walls. The solid limestone

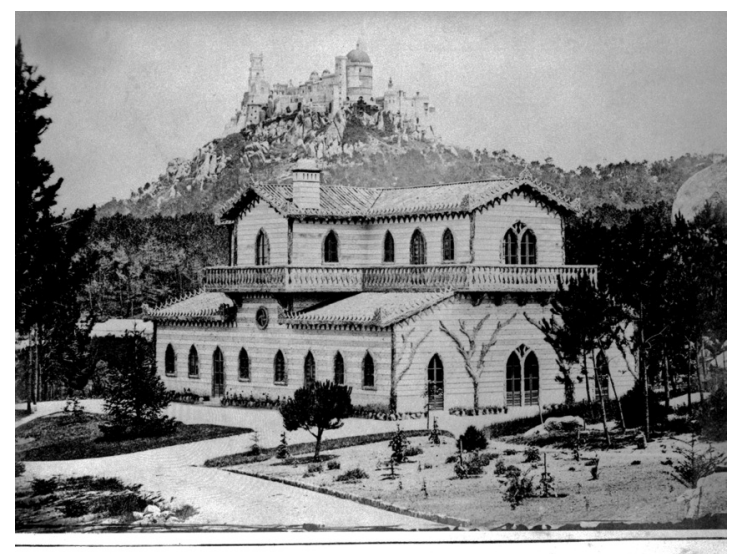

SWISS CHALET IN NEW GARDEN.

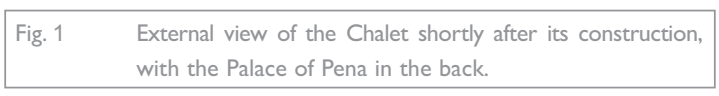

masonry structure resisted well, the fire consumed the wooden structure. It also had a destructive effect on the stone slabs from the cantilevered veranda (figure 2).

Following the successful bidding for financial support form the EEA Grants, a partnership was created between Parques de Sintra-Monte da Lua and several national and international partners, with particular mention to the Norwegian Institute for Cultural Heritage (NIKU) and the cleaning operation and salvage selection was carried between September and October 2007.

In order to study the execution of new internal renders compatible with the existing ones (both for partition and masonry walls), the Department of Civil Engineering, from Universidade Nova de Lisboa (a national partner in the project) was responsible for scientific analysis of mortar samples, in order to characterize the properties that will determine the new formulations to be applied, like capillary water absorption, drying and water vapour permeability and the microstructural properties. Additionally, the internal decorative renders recovered from the fire (salvage) were also the object of careful removal, selection and analysis regarding its composition, layering, original colours and pigments used. This analysis was conducted by the Instituto Português de Conservação e Restauro (IPCR - IMC), another national partner of the project. This paper describes the preliminary evaluations.

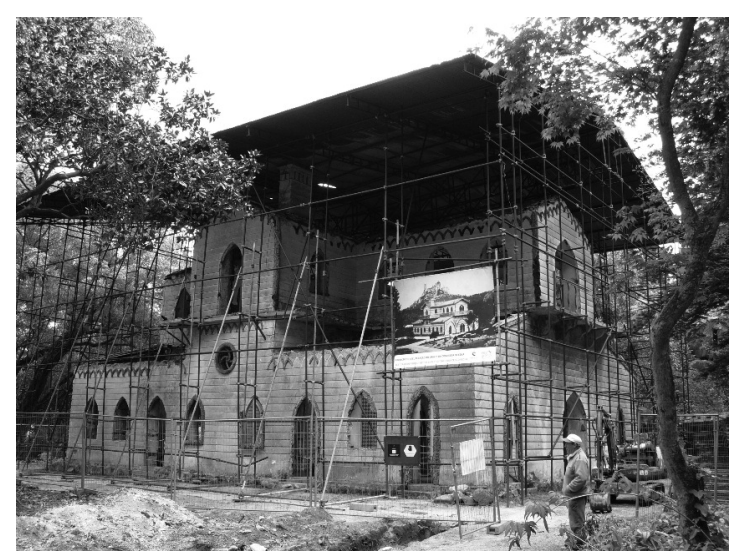

Fig. 2 Current condition after the fire in 1999 (September 2007). 


\section{Experimental campaign and results}

The internal renders are made of two mortar layers and one final plaster layer onto which the decorative surfaces were apposed. One of the mortar layers was applied directly on the wooden base (layer A) and the other, an intermediate mortar (layer B) intended to be the substrate for the plaster. In this preliminary study the plaster layer was not analysed. A set of seven fragments was collected from which the samples for testing were taken to evaluate the following materials:

- Pigments of the pictoric layer;

- Mortar of layer A (open porosity and mercury intrusion porosimetry). Samples used are from room 6 and the staircase (figure 3); in both cases, non-affected mortars (samples R6.1 and St.1) and fire-affected mortars (samples R6.1f and St.1f) were analysed;
- Mortars of layers A and B (binder:aggregate ratio). Samples used are also from room 6 and the staircase. The sample of layer $A$ from the staircase was fire-affected whilst the other ones were non-affected by fire.

\section{Pigments}

\section{प X-Ray diffraction}

The composition of the pictoric layer was identified by $X$-Ray diffraction with a Bruker AXS equipment, model D8 Discover with $\mathrm{Cu} \mathrm{K} \alpha$ radiation, GADDS detector and using ICDD (International Centre for Diffraction Data) cards; the collimator diameter has $1 \mathrm{~mm}$ (the diameter of the beam on the sample).

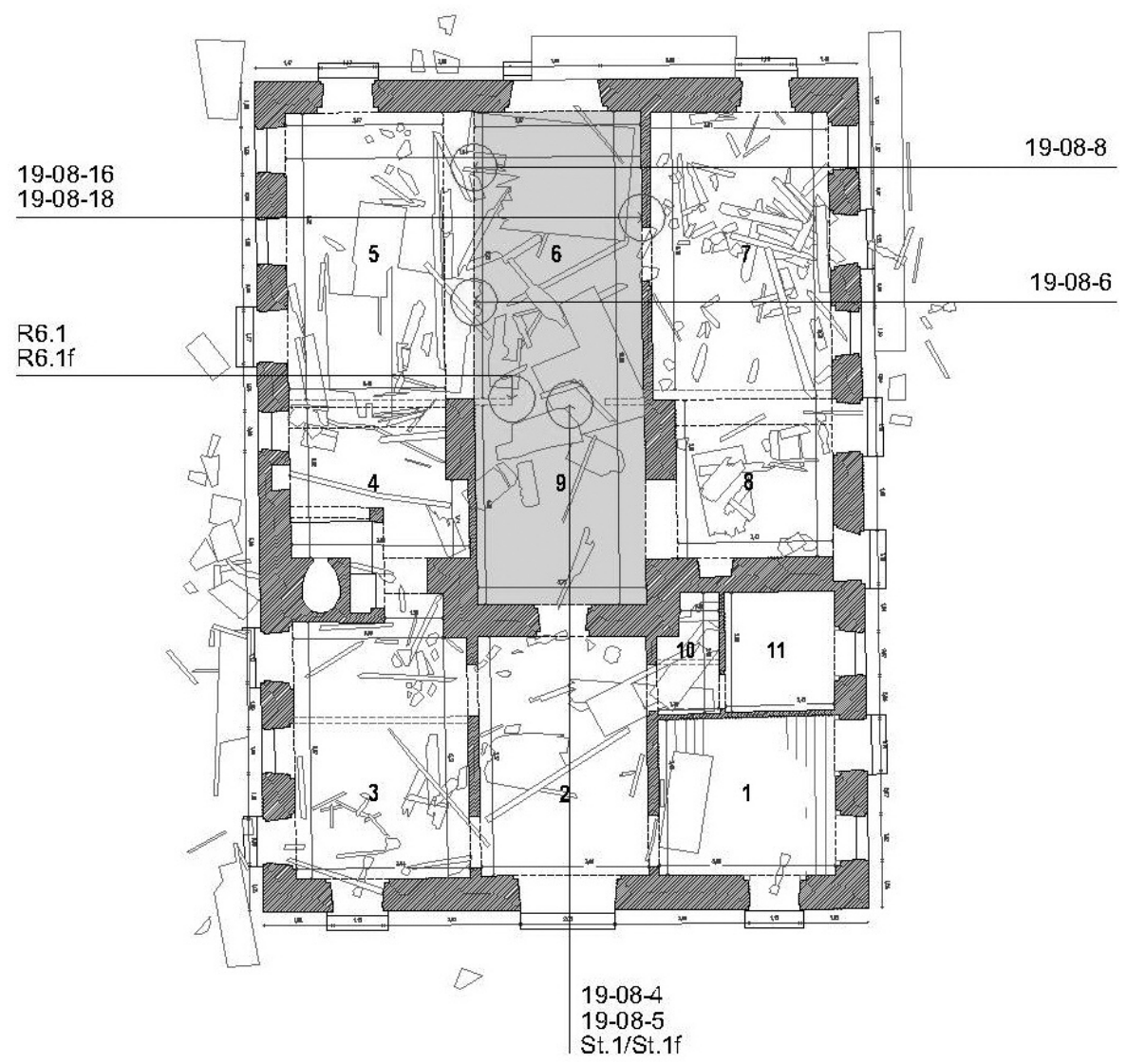




\begin{tabular}{|c|c|c|}
\hline \multicolumn{2}{|c|}{ Samples } & \multirow{2}{*}{ Identified Phases } \\
\hline References & Layerl Colour & \\
\hline $\begin{array}{c}19-08-1 \\
\text { 1st fl., Broderies Room }\end{array}$ & Dark blue & Calcite, Quartz, Barite, Lazurite \\
\hline $\begin{array}{c}19-08-2 \\
\text { 1st fl., Broderies Room }\end{array}$ & Light blue & Calcite, Quartz, Lazurite \\
\hline $\begin{array}{c}19-08-3 \\
\text { 1st fl., Broderies Room }\end{array}$ & White & Calcite \\
\hline $\begin{array}{c}19-08-4 \\
\text { Staircase hall }\end{array}$ & Red (decoration) & Calcite, Quartz, Hematite, Kaolinite, Cinnabar \\
\hline $\begin{array}{c}19-08-5 \\
\text { Staircase hall }\end{array}$ & Red (background) & Calcite, Quartz, Kaolinite, Cinnabar \\
\hline $\begin{array}{c}19-08-6 \\
\text { Ground fl., Living Room }\end{array}$ & Red (decoration) & Calcite, Quartz, Kaolinite, Hematite \\
\hline $\begin{array}{c}19-08-7 \\
\text { Ground fl., Living Room }\end{array}$ & Red (background) & Calcite, Quartz \\
\hline $\begin{array}{c}19-08-8 \\
\text { Ground fl., Living Room }\end{array}$ & Yellow (decoration) & Calcite, Quartz, Kaolinite, Goethite \\
\hline $\begin{array}{c}19-08-9 \\
\text { Ground fl., Living Room }\end{array}$ & Yellow (background) & Calcite, Quartz \\
\hline
\end{tabular}

\begin{tabular}{|c|c|c|}
\hline \multicolumn{2}{|c|}{ Samples } & \multirow{2}{*}{ Identified Phases } \\
\hline References & Layer/ Colour & \\
\hline $\begin{array}{l}\text { 19-08-10 } \\
\text { 1st fl., Cork R. }\end{array}$ & White & Calcite, Quartz \\
\hline $\begin{array}{l}\text { 19-08-11 } \\
\text { 1st fl., Cork R. }\end{array}$ & Red (decoration) & Calcite, Quartz, Hematite \\
\hline $\begin{array}{l}\text { 19-08-12 } \\
\text { 1st fl., Cork R. }\end{array}$ & Black (alteration) & Calcite, Quartz \\
\hline $\begin{array}{l}\text { 19-08-13 } \\
\text { Ground fl., Living Room, Upper frise }\end{array}$ & Red (decoration) & Cinnabar, Hematite, Calcite \\
\hline $\begin{array}{l}\text { 19-08-14 } \\
\text { Ground fl., Living Room, Upper frise }\end{array}$ & Gray (decoration) & Calcite, Quartz, Barite, Lazurite \\
\hline $\begin{array}{l}\text { 19-08-15 } \\
\text { Ground fl., Living Room, Upper frise }\end{array}$ & Red (Background) & Calcite, Quartz, Hematite, Kaolinite \\
\hline $\begin{array}{l}\text { 19-08-16 } \\
\text { Ground fl., Living Room, Upper frise }\end{array}$ & Red (decorative motif) & Calcite, Quartz, Hematite, Gypsum \\
\hline $\begin{array}{l}\text { 19-08-17 } \\
\text { Ground fl., Living Room, Upper frise }\end{array}$ & $\begin{array}{c}\text { Brown (colour alteration of the } \\
\text { decorative motif) }\end{array}$ & Calcite, Quartz, Hematite, Gypsum \\
\hline $\begin{array}{l}\text { 19-08-18 } \\
\text { Ground fl., Living Room, Upper frise }\end{array}$ & $\begin{array}{c}\text { Black (colour and chemical } \\
\text { alteration of the decorative motif) }\end{array}$ & Calcite, Quartz, Magnetite, Gypsum \\
\hline $\begin{array}{l}\text { 19-08-19 } \\
\text { Ground fl., Living Room, Upper frise }\end{array}$ & White & Calcite, Quartz \\
\hline
\end{tabular}


Table 1 and table 2 show the compounds identified in the samples 19-08-1 to 19-08-19.

Figures 4 to 9 show the fragments from which samples were collected. In some of these, it was possible to analyse the pigment in its original phase and also in its altered phase (darkened areas).

The samples 19-08-6 and 19-08-8 (figure 6) are both of the living-room and concerning the same decoration pattern, with decorative motives painted on the same substrate. The colour of this substrate is a rose tone in most areas, where the identified pigment is hematite. In some small areas, it has a light yellow tone where the identified pigment is goethite. It is not likely that these differences in colour were intentional in a decorative substrate with symmetrical patterns. Therefore, the effects of fire or the action of the water used by firemen have most probably caused a phase change in the original pigments. In order to explain this, two approaches are possible:

- The original pigment was goethite and the decorative substrate was yellow. The heat of fire has dehydrated the goethite with the consequent phase change to hematite that originates the rose tone. In some residual areas the temperature may not have been high enough for this phase change to occur and therefore some scattered yellow areas remained corresponding to the original goethite;

- The original pigment was hematite and the decorative substrate was of a rose tone. In this case, water absorption on some areas of the surface, together with the very humid local climate, have caused the hydration of the hematite with the consequent phase change to goethite which in turn caused the colour change to yellow.

The second approach seems more plausible because the uniformity of the rose colour in most of the painted areas in this room is more in agreement with an original application of a homogeneous colour. In this case the yellow areas should therefore correspond to affected and altered material.

Also, the results of the samples 19-08-16 and 19-08-18 of the living room (figure 7), concerning a decoration near the ceiling, show the change of hematite to magnetite, a different phase of oxidation, probably caused by fire, and giving rise to a colour change from the original reddish to black.

The graphic of figure 10 shows the results of sample 19-08-16 (hematite) and the graphic of figure 11 shows the results of sample 19-08-18 (magnetite).

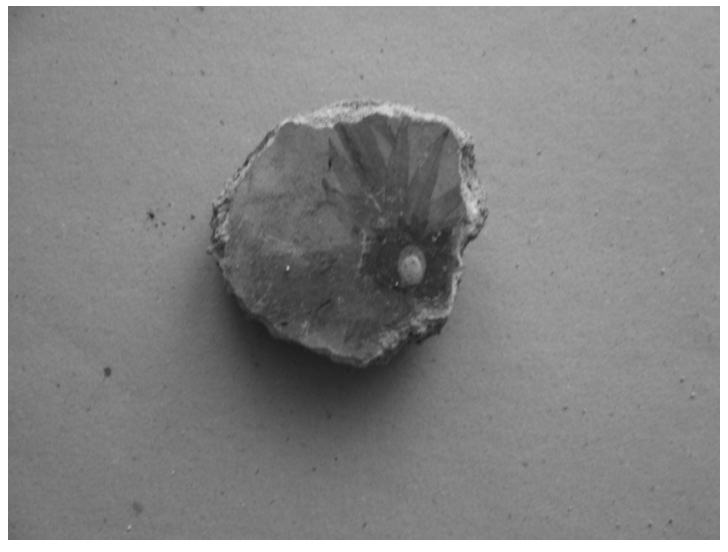

Fig. 4 Samples 19-08-10 to 19-08-12.

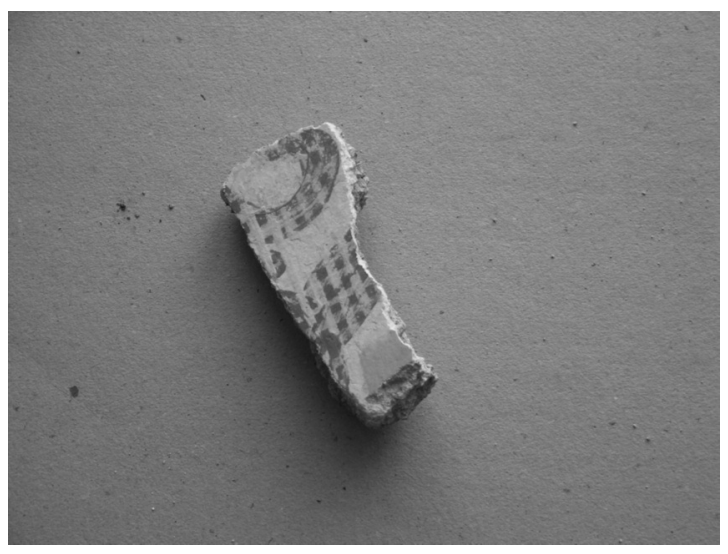

Fig. 5 Samples 19-08-01.

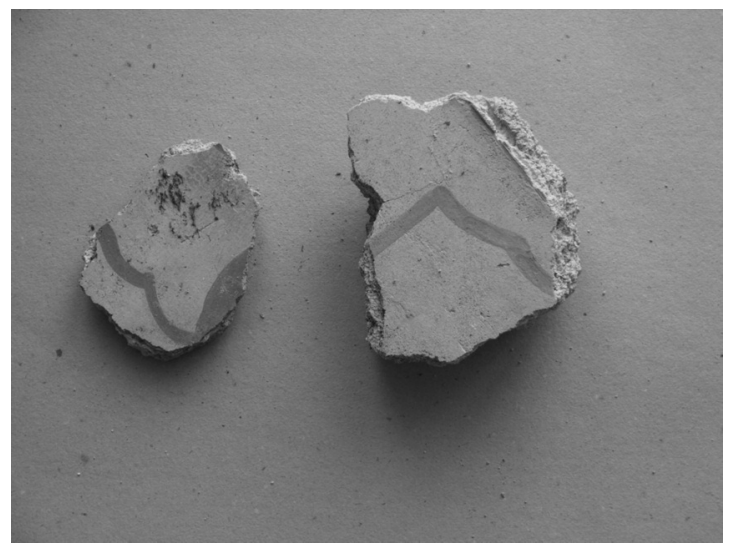

Fig. 6 Samples 19-08-6 to 19-08-9. 


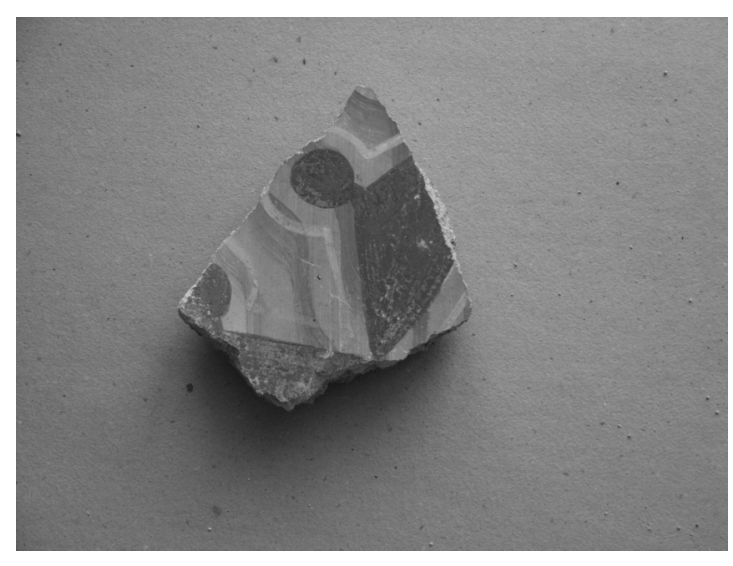

Fig. $7 \quad$ Samples 19-08-16 to 19-08-18.

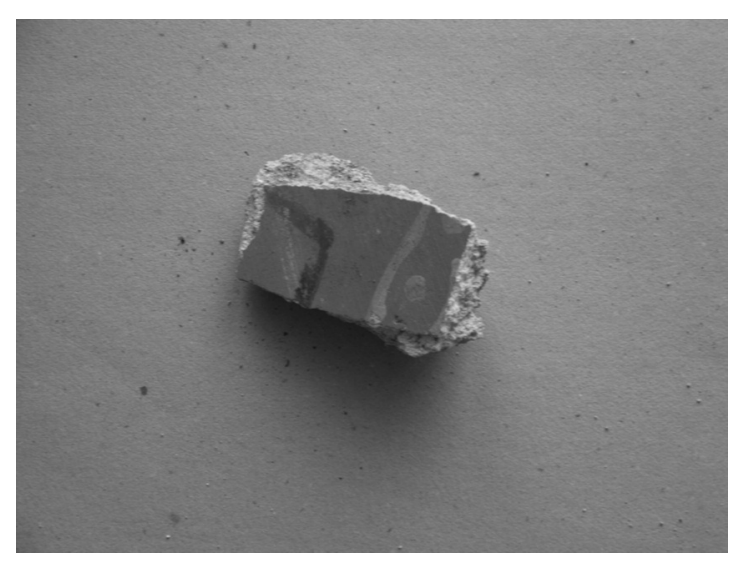

Fig. 8 Samples 19-08-13 to 19-08-15.

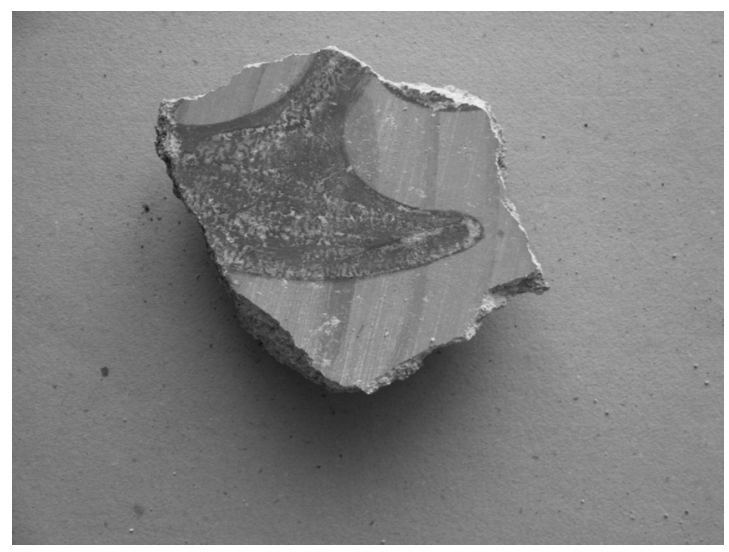

Fig. 9 Samples 19-08-4 to 19-08-5.

\section{Mortars}

\section{Density and open porosity}

The four collected samples were analysed for the determination of the apparent density and the open porosity. Before testing, samples were dried at $60^{\circ} \mathrm{C}$ to constant mass. The test procedure was based on the European Norm EN 1936 [1], by total saturation with water under vacuum and hydrostatic weight. Results are presented in figure 12 .

It may be observed that the mortars have very similar apparent densities and open porosities. Nevertheless, comparing mortars R6.1 and R6.1f and mortars St.1 and St.1f, there is a slight trend that may indicate that mortars subjected to high temperatures were altered in such a way that open porosity is slightly increased. This trend shall be further investigated with new collected samples both affected and non-affected by fire. On the other hand, in order to better evaluate this possible effect, non-affected mortars will be submitted to high temperatures in the laboratory and then tested.

\section{Mercury porosimetry}

Pore-size distribution was performed with a mercury porosimeter on each collected mortar. Samples were dried to constant mass at $60^{\circ} \mathrm{C}$. Two equivalent penetrometers were used with a $5 \mathrm{~cm}^{3}$ bulb and a total intrusion capacity of $1.716 \mathrm{~cm}^{3}$. Low pressure testing ranged from $0.0138 \mathrm{MPa}$ (2 Psi) to 0.1979 $\mathrm{MPa}$ (28.7 Psi) and high pressure analysis from $0.2124 \mathrm{MPa}(30.8 \mathrm{Psi})$ to 206.4063 MPa (29936.7 Psi). Equilibration times were 10 seconds for both low and high pressures. As mercury parameters, the following were used: advancing and receding contact angle $=140^{\circ}$; surface tension $=0.485$ $\mathrm{N} / \mathrm{m}$; density $=13.5335$.

Cumulative and incremental curves are plotted in figures 13 and 14. These plots represent the pore size diameter in microns and each step of mercury intrusion in percentage of total intrusion.

These bimodal pore-size distribution curves are typical of non-hydraulic lime mortars [2, 3]. This type of distribution is the result of a well interconnected macropore network that is formed as a result of the drying 

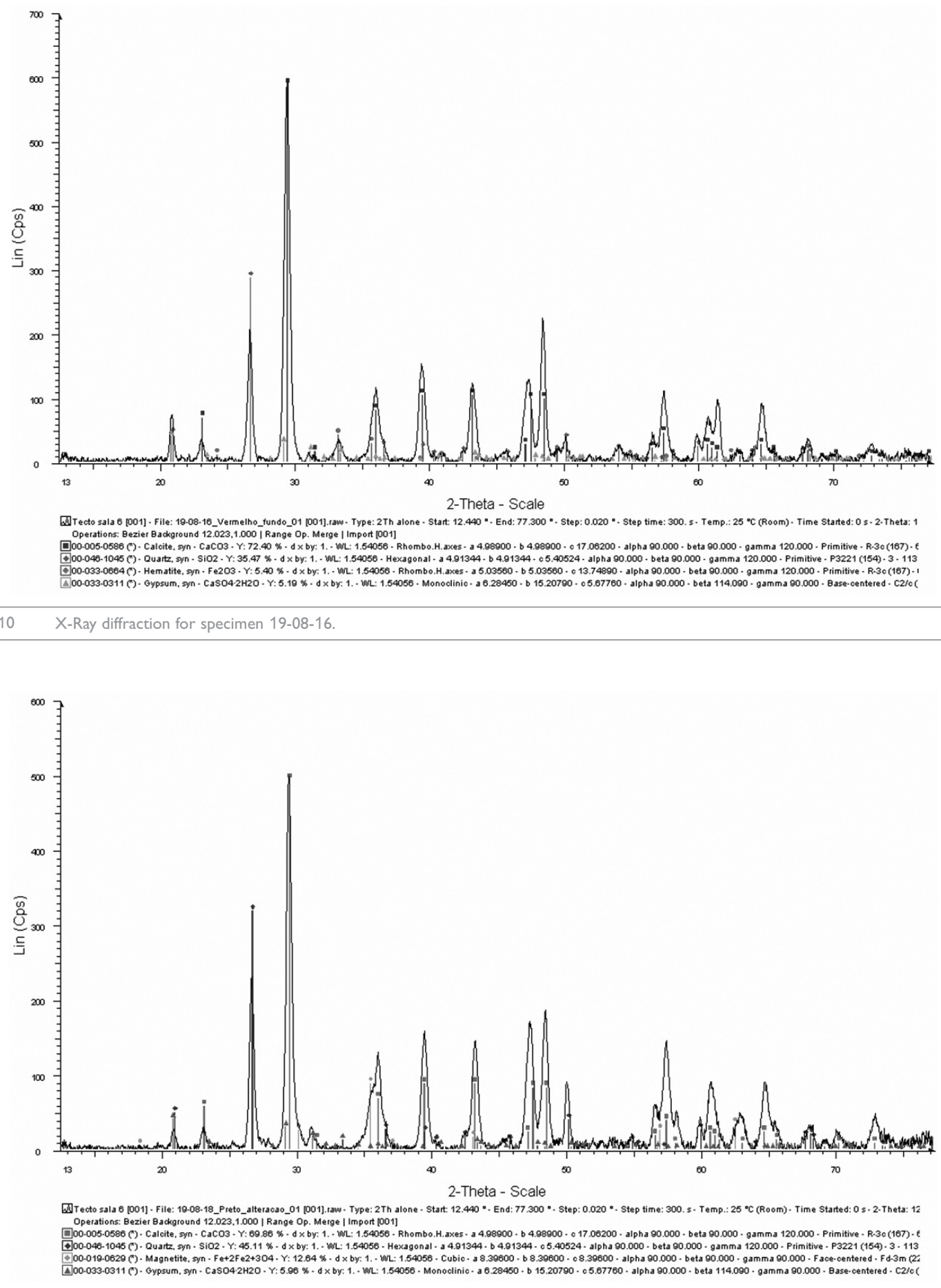

Fig. $11 \quad$ X-Ray diffraction for specimen 19-08-18. 


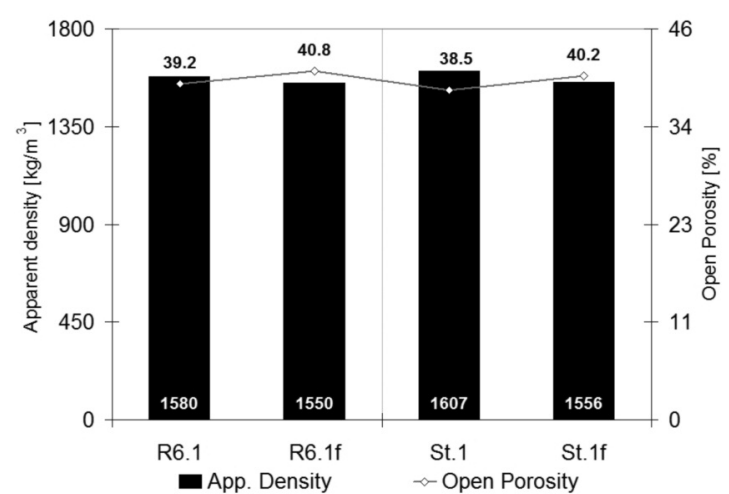

Fig. 12 Apparent density and open porosity of the mortars.

shrinkage of lime mortars [4]. This macropore network is more significant in mortars R6.1 and R6.1f. This can be confirmed by higher values in the first intrusion [5], corresponding, in this case, to the accessible and interconnected pores with diameters above $108 \mathrm{~mm}$. In the range of the smaller pores, all of the mortars have important threshold diameters of $0.1 \mathrm{~mm}, 0.2 \mathrm{~mm}, 1.0$ $\mathrm{mm}$ and $1.5 \mathrm{~mm}$.

In a first approach, it can be said that the main differences in pore-size distribution are not related to the effect of fire. Mortars R6.1 and R6.1f have very similar intrusion curves and the same can be observed with mortars St.1 and St.1f. Therefore, these differences appear to be related to the area where samples were collected. It would not be surprising if mortars applied on different rooms of the building would have dissimilarities in their internal structures. As it is well known, this could arise from different manpower, curing conditions, amount of mixing water, etc.

One fact deserves however a specific reference: mortars St.1 and St.1f were collected from the area of the building that was the most affected by the fire. The significant distinction on the respective intrusion curves in the range of the 1.0 to $1.5 \mathrm{~mm}$ diameters is therefore a feature that will deserve a more detailed analysis together with the future tests of open porosity previously mentioned.
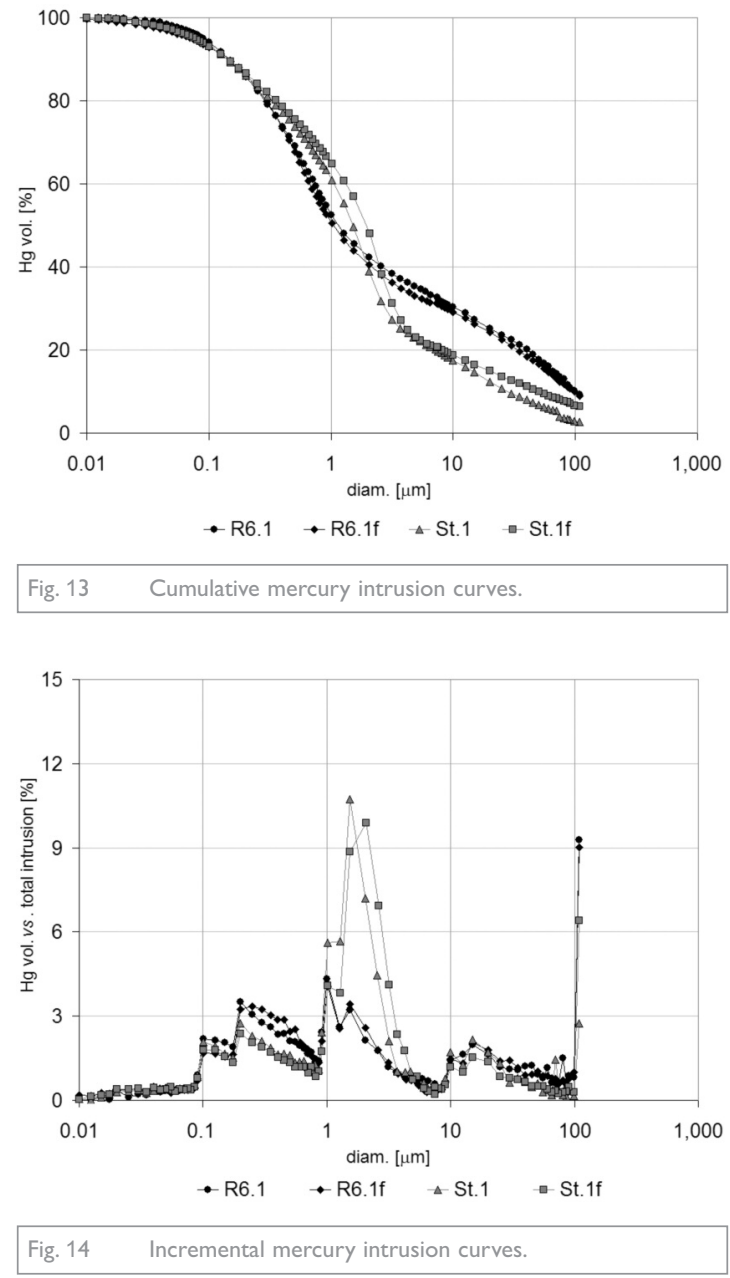

\section{Binder : aggregate ratio}

The identification of the binder : aggregate ratio was obtained by the method of dissolution of the carbonates with hydrochloric acid and weighting (table 3). Although there is no information about the origin of the sands used in the construction of the chalet, most probably local siliceous sands were used. Therefore the results of this particular test should not be affected because the sand has no calcareous elements in its composition.

Results for the two layers of the two samples that were analysed are very similar (1:4 and 1:5 by weight); it was not therefore possible to establish any distinction related to the effects of fire in this particular feature. 


\begin{tabular}{ccccc}
\hline Table $3 \quad$ Composition and binder : aggregate ratio of mortars. & & & \\
\hline Compounds & $\begin{array}{c}\text { Room 6 } \\
\text { Layer A }\end{array}$ & $\begin{array}{c}\text { Room 6 } \\
\text { Layer B }\end{array}$ & $\begin{array}{c}\text { Staircase } \\
\text { Layer A }\end{array}$ & $\begin{array}{c}\text { Staircase } \\
\text { Layer B }\end{array}$ \\
\hline Calcium carbonate binder (\%) & 18.80 & 14.26 & 16.71 & 73.48 \\
\hline Aggregates (\%) & 74.67 & 77.45 & 4.46 & 3.35 \\
\hline SiO2 soluble (\%) & 3.95 & 3.01 & 4.05 & 3.28 \\
\hline Organic matter + H2O (Renderings) (\%) & 2.12 & 2.72 & 98.72 & 98.02 \\
\hline Total (\%) & 99.55 & 97.44 & 1.28 & 1.98 \\
\hline Bndeterminated (\%) & 0.45 & 1.56 & $1: 4$ & 1.4 \\
\hline
\end{tabular}

\section{Conclusions}

In what concerns the microstructural properties of the mortars, it seems in a first approach that there was not significant damage caused by fire. The effects of fire temperatures on the superficial plaster layer have probably caused a dehydration of the gypsum which, in turn, would lower the thermal conductivity. In this way, the mortar substrate would be less affected. On the other hand, it can be observed on the samples that the carbonation of the inner wooden structure of the walls has caused some superficial changes on the subsequent mortar layers. Nevertheless, the results obtained in this preliminary study show that these effects were not as serious as to cause important alterations in the material.

The effects of fire in the Chalet's fabric are not yet fully clear; however there are some interesting findings. Evidence gathered so far suggests that the fire has not reached enough temperature in order to alter significantly the physical properties of the mortars, but it caused interesting alterations to the integral decorated surfaces. Pigments analysed showed colour changes indicating slow combustion of the fabric, eventually up to $400{ }^{\circ} \mathrm{C}$, judging by the phase change of the hematite to magnetite. Additionally, the relative stability of mortars indicates that temperatures were not high enough to alter the calcium carbonate, otherwise there would probably be some cracking in the internal renders and detectable changes in the properties of their microstructure.

\section{References}

1 CEN, EN 1936. Natural stone test methods. Determination of real density and apparent density and of total and open porosity, CEN, Bruxels (1999)

2 Lanas, L.; Alvarez, J., 'Masonry repair lime-based mortars: factors affecting the mechanical behaviour', Cement and Concrete Research 33 (2003) 1867-1876

3 Faria, P.; Henriques, F.; Rato,V., 'Comparative evaluation of aerial lime mortars for architectural conservation', Journal of Cultural Heritage 9(3) (2008) 338-346.

4 Rato, V., 'A influência da microestrutura morfológica no comportamento de argamassas', PhD dissertation, Universidade Nova de Lisboa (2006).

5 Rübner, K.; Hoffmann, D., 'Characterization of mineral building materials by mercury-intrusion porosimetry', Particle and Particle Systems Characterization 23(1) (2006) 20-28. 